\title{
A Survey on Needs for English Academic Course for Doctoral Candidates
}

\author{
Xiaoqin Yan \\ Foreign Languages College, Jiangxi Normal University, Jiangxi, China \\ Fangfang Zou \\ Foreign Languages College, Jiangxi Normal University, Jiangxi, China
}

\begin{abstract}
Teaching of English for Academic Purpose (EAP) has caught great attention to developing the academic literacy of doctoral candidates. Therefore, it is a necessity to investigate their learning needs towards EAP courses. The paper did a survey on 105 doctoral candidates from 9 dimensions to investigate their overall situation of EAP learning needs. Teaching implications on EAP course concern teacher qualities, curriculum design and teaching practice.
\end{abstract}

Index Terms — needs analysis, English for Academic Purpose, doctoral candidates

\section{INTRODUCTION}

Reading volumes of international issues, presenting lectures in English and publishing articles in overseas magazines all pose a great challenge to the academic English literacy of non-English major doctoral candidates. According to the English Teaching Syllabus for the doctoral program (1992) issued by the Ministry of Education in China, English teaching aims to "help students to develop skillful reading competence, good writing and translating competence and sufficient listening and speaking competence; and students should be able to conduct research and make academic exchanges in their discipline in English.” Administers, schools and teachers have to try their best to accomplish this goal.

Despite huge progress in doctoral candidates' English teaching in most Chinese universities, many problems such as weak academic English pragmatic ability hinder doctors' English academic literacy. Accordingly, most universities have already set up EAP course for doctoral candidates. Nevertheless, it is not enough in that course syllabus is designed mainly on the basis of education policy-makers and teaching faculty's experience and command. The effect has proven that it can't reflect massive students' actual learning needs. In this sense, as the key role in learning, doctoral candidates' learning needs should be considered firstly for the cultivation of their academic literacy.

\section{LITERATURE REVIEW}

\section{A. Classification of Needs}

Needs are the distance from a current state to a desired future state (Berwick, 1989) in terms of psychology. Widdowson (1987) claims that learning needs are goals of learners' study such as the expectation for their learning ability after they finish the language program or course. With regard to language learning, Robinson (1991) holds that needs represent what the learners do not know or are not able to do in learning and using English. Language deficiency is defined as the difference between the current language ability and the expected language learning ability (Richards, 2001).

Classifications of needs are made from different orientations. For example, needs are divided into target needs and learning needs (Hutchinson and Waters, 1987). Target needs can be analyzed from learners' necessities, such as necessities for learners' language use; learners' lacks in a language learning; and learners' wants for language production.

\section{B. Models of Needs Analysis}

Needs analysis, first introduced to language teaching through the ESP movement from the 1960s (Richards, 2001), is conducted to collect information about learners' needs through various methods such as questionnaires, interviews, observation.

Typical needs analysis models are Target Situation Analysis proposed by Munby (1978), and the model of Dudley-Evans and St. John (1998).

Target Situation Analysis model, oriented by learners' future career prospects or academic situation, addresses the

* This research was supported by the grant of Research Project of Teaching Reform of Degree and Postgraduate Education in Jiangxi Province (On the construction of "academic English" curriculum for non-English major doctoral candidates JXYJG-2019-040). 
language requirements. Munby (1978) claims that analyzing learners' communicative needs serves as the cornerstone of determining learning contents. Curriculum designers must analyze learners' present language proficiency level in the target situation through questionnaire, interviews etc. before curriculum development. The model of Hutchinson and Waters (1987) initiates the learner-centered analysis. They argue that it is necessary to describe learners' learning needs and target needs before a lesson begins. The model of Dudley-Evans and St. John (1998) consists of eight parts: learners' personal information, information about learners' profession, language proficiency, language learning, lack of learners, curriculum needs, learners' learning environment information and how to apply language and skill knowledge in the target situation.

The study is designed based on Hutchinson and Waters' model (1987), in which a framework for target situation analysis (1987) and a framework for analyzing learning needs are provided. The former covers why the language is needed, how the language will be used, what the content areas will be, where and when the language will be used; the latter includes why the learners are taking the course, how they learn, what resources are available, who the learners are, where the EAP course will take place and when the EAP course will take place. The framework shows the whole process of learning and introduces researchers how to construct a questionnaire to carry out needs analysis.

\section{Empirical Researches on Needs Analysis}

During the past 20 years, enormous contribution has been made to develop needs analysis research. In a comparative study of EAP programs conducted in universities in New Zealand and Vietnam, Oanh (2007) aims to find out whether needs analysis receives any attention in the program through both class observation and interviews. It shows both universities have somewhat considered learners' needs for the EAP program. Sultana (2018) argues that needs analysis is an invaluable step for learners to achieve successful autonomous English learning. In his study, 25 respondents at tertiary level in a Basic English course were invited to finish questionnaire-1 concerning learning needs before the course; questinnnaire-2 relating to need assessment in the middle of the course and questionaore- 3 after the course. The results reveal, in autonomous class, a direct link can be drawn from learning needs to course design, fruitful classroom implementation and successful outcomes. Iizuka (2019) attaches great importance to implementing needs analysis for curriculum construction, and stresses the more frequent and systematic implementation of needs analysis in curriculum construction after exploring the communicative needs of studying abroad in Japan, adopting multiple sources including students and host families and multiple methods covering semi-structured interviews and questionnaires.

Other studies sought to dig out the needs of subjects. To find out what computer science students' needs are in ENG 101 and ENG 102 courses in terms of academic skills for the curriculum renewal project, Yürekli (2012) identified students' different needs with respect to 5 areas of academic skills (listening, reading, speaking, writing and research skills) and 2 linguistic competences (vocabulary and grammar). To investigate the efficiency of EAP courses and the extent to which these courses meet both academic and work-related needs of future pharmacists, Chowdhury and Haider (2012) adopted a structured questionnaire with questions about learners' current English learning needs and expectations. As a result, the study highlights writing and speaking skills in EAP course and the gap between academic and vocational language needs. To study the learning needs of English learners and their real needs of using English at the workplace, Chen, Chang and Chang (2016) administer a questionnaire to 30 senior college students and 30 employers. The results show college students and employers share different needs towards English; specifically, employees are required to be excellent at listening and speaking; however, the language in communication situations is less taught. The study points out the mismatch between English teaching in classroom courses and the real language needs in the workplace.

Nafissi, Rezaeipanah and Monsefi (2017) conducted a questionnaire survey about course evaluation among 20 undergraduates after they took the short and intensive ESP course. The results reveal most participants call for more EAP courses at universities. Mohammed (2016) explored the application of needs analysis in developing EAP materials for business students in two Sudanese universities. Two head departments of English language were interviewed. The qualitative outcomes concluded that most of the EAP materials in business administration are not relevant to students' learning and target needs for lack of needs analysis in designing a course.

Based on Hutchinson \&Waters's (1987) framework of target needs, Uzun (2018) investigated the EAP needs of the research assistants of nursing in a public Turkish university through an open-ended questionnaire. The findings reveal that participants hold the need to improve their academic speaking and writing skills to write research articles and give presentations in international conferences. To explore how various stakeholders perceive task-based pragmatic needs in an EAP class, Youn (2018) interviewed administrators, teachers and students who also had to finish a questionnaire with a series of questions about real-life EAP language use situations. Different stakeholders expressed relatively strong pragmatic needs and lower-proficiency level students showed stronger pragmatic learning needs compared with higher ones. Menggo, Suastra, Budiarsa \& Padmadedwi (2019) investigated 312 English majors to find out their target needs and learning needs toward academic English materials development with a questionnaire and in-depth interview. The result shows that learners' target needs cover necessities, lacks and wants; learning needs include input, procedure, setting and learners' role.

In order to examine why academics and graduate students cannot acquire the second language academic literacy, Köse, Yüksel, Öztürk, \& Tömen (2019) conducted a large-scale survey to dig out the needs of academics and graduates across different disciplines in Turkey. The findings suggested that the subjects need most of the listed competencies 
including reading, writing and listening; and their needs are language-skill specific, which is helpful to EAP teaching in various dimensions in Turkey.

From the above, most of the research aimed at the needs analysis of learners when designing the EAP course, few of which investigated the students of doctoral stage. In this background, the study explores the learning needs of doctoral candidates in universities of Jiangxi Province towards EAP course from nine dimensions, in the hope of providing some implications to better EAP curriculum and EAP teaching for tertiary universities.

\section{RESEARCH DESIGN}

\section{A. Research Questions}

In order to get a clear picture of doctor candidates' learning needs toward EAP course, this study is going to address the following question: What are the specific needs for doctoral candidates' EAP learning?

\section{B. Participants}

The study randomly selected 105 subjects who are pursuing doctoral degrees of different majors other than English in three universities in Jiangxi Province. Among them, 46 students are male and 59 are female, who are supposed to get 4 course credits after taking two English courses of listening and speaking, reading and writing for a whole school year in their doctoral programs. Most of the subjects have average English literacy, but with poor oral communicative competence. They are liable to lose their interest in training general English skills for lack of specific requirement on English use in their daily research or work. The courses were originally designed to further develop their general English competence, instead of the academic literacy, which may be a hindrance for the candidates to attend international academic symposium or publish academic papers in international journals, which can ensure their smooth graduation or career promotion on account of higher requirements on academic achievements of doctoral candidates in their universities.

\section{Research Instruments}

The needs analysis questionnaire of academic English learning for Phd. candidates is adopted and revised according to Shu Dingfang's (2004) classification of needs and Chen Bingbing's (2010) model of needs analysis. The questionnaire on a 5-point Likert Scale ranging from 1 (strongly disagree) to 5 (strongly agree) is composed of two parts. The first part is about the personal information covering gender, age, major, grade, the English level of entering doctoral stage and the time of postgraduate graduation. The second part consists of 39 items with nine dimensions of needs listed as follows: (1) learners' individual wants (Item 1, 12, 22, 32, 35); (2) learner' learning motivation (Item 2, 13, 23, 28, 33); (3) learners' learning strategy (Item 3, 14, 36); (4) teachers' quality (Item 4, 15, 25, 39); (5) curriculum design (Item 5, 6, 16, 26); (6) classroom teaching (Item 7, 17, 27, 37); (7) learning resources (Item 8, 10, 18, 20, 30); (8) teaching materials (Item 9, 19, 24, 29, 34, 38); (9) assessment method (Item 11, 21, 31).

\section{Data Collection}

The questionnaire was delivered to 105 non-English doctoral candidates in December, 2019 with the help of their English teachers. All items are presented in Chinese to avoid language barriers. Every subject was informed of the general purposes and instructions for filling in the questionnaire. It took every student 15 minutes to finish all the questionnaire items carefully. For some reasons, 5 students didn't finish the questionnaire effectively; hence, only 100 participants' test results were valid in this study.

\section{E. Data Analysis}

All the data collected were input into the computer and analyzed by the Statistical Package for the Social Science (SPSS, version 22.0). The reliability test of the questionnaire, descriptive analysis, and independent sample T-test were adopted to find out the overall situation of doctor candidates' learning needs in EAP class. The results are displayed through mean value and other indicators as follows.

\section{RESULTS AND DISCUSSIONS}

Firstly, the reliability result shows the Cronbach coefficient of the questionnaire is .938 that is largely higher than .70. Thus, the questionnaire is proved to be of high reliability and validity.

\section{Overall Situation of Doctoral Candidates' EAP Learning Needs}

The results in Table 1 reveal the general situation of EAP learning needs in detail. The mean value of the whole questionnaire is 4.03 ( $\mathrm{SD}=.9228$ ), which indicates that the doctoral candidates in three universities have high demand for academic English courses. As for the 9 dimensions of EAP learning needs, the mean values varied - 4.29 (SD=.59) for learning resource, followed by $4.26(\mathrm{SD}=.63)$ for learners' individual wants, $4.22(\mathrm{SD}=.62)$ for learners' learning strategy, $4.1(\mathrm{SD}=.61)$ for classroom teaching, $4.08(\mathrm{SD}=.66)$ for teaching material, $4.06(\mathrm{SD}=.74)$ - for assessment method, $3.90(\mathrm{SD}=1.27)$ for teachers' quality, $3.83(\mathrm{SD}=.91)$ for curriculum design, and 3.57 ( $\mathrm{SD}=1.02)$ for learners' learning motivation. 
TABLE 1

GENERAL DESCRIPTION OF EAP LEARNING NEEDS OF DOCTORAL CANDIDATES

\begin{tabular}{ccc}
\hline Dimensions & Mean & Standard Deviation \\
\hline Learners' individual wants & 4.26 & .63 \\
Learners' learning motivation & 3.57 & 1.02 \\
Learners' learning strategy & 4.22 & .62 \\
Teachers' quality & 3.90 & 1.27 \\
Curriculum design & 3.83 & .91 \\
Classroom teaching & 4.15 & .61 \\
Learning resource & 4.29 & .59 \\
Teaching material & 4.08 & .67 \\
Assessment method & 4.06 & .74 \\
The Whole Questionnaire & 4.04 & .92 \\
\hline
\end{tabular}

All mean values of the whole questionnaire and nine dimensions are above 3.5 , which is a sign of relatively strong EAP learning needs of doctoral candidates generally.

Specifically speaking, both the mean value of learning resource and learners' individual wants are higher than 4.00, indicating that the doctoral candidates are unsatisfied with the resources they can access from school and they truly need to improve their EAP competence in listening, reading, speaking, writing and translation. In addition, the participants' needs toward the strategies they adopted, the way their teachers impart the knowledge, what materials to be covered and the method to assess their learning results when learning EAP course are slightly strong. Lastly, the teaching staff at school proves to be very strong and curriculum in EAP course is quite appropriate for the candidates. Learning motivation, being the lowest mean, suggests as a doctoral candidate, participants really want to learn the course well. The detailed analysis of these dimensions is shown below.

\section{Situation of Learners' Individual Wants}

Table 2 presents the frequencies and occurrence rates of responses for the five items of the subjects' EAP wants in the questionnaire, and the mean and standard deviation of each item are displayed respectively as well.

TABLE 2

\begin{tabular}{cccc} 
& RESUlTS OF LEARNERS' INDIVIDUAL WANTS & \\
\hline Component & Items & Mean & Standard Deviation \\
& & & \\
\hline \multirow{2}{*}{ Learners' individual wants } & Listening & 4.39 & .92 \\
& Reading & 4.36 & 1.00 \\
& Speaking & 4.21 & .98 \\
& Writing & 4.26 & .98 \\
& Translation & 4.10 & 1.04 \\
\hline
\end{tabular}

As is shown in Table 2, the mean of all the items including listening, reading, speaking, writing and translation in EAP course are higher than 4.0 with listening $(\mathrm{M}=4.39, \mathrm{SD}=.92)$ being the highest, which indicates learners' desires to improve EAP skills are at a strongly high level and they especially desire to improve their listening proficiency. Moreover, the rank of means is in accordance with the rank of agree and strongly agree percentage. $86 \%$ students hold that they want to improve their EAP listening skills most, $87 \%$ students for the reading skills most, $81 \%$ students for speaking skills most, $82 \%$ students for writing skills most, and $77 \%$ students want to improve their translation skills most. It is clear that over $70 \%$ of doctoral candidates' desire to make progress in every aspect of EAP skills.

The result shows doctoral candidates' real situation towards EAP course. It reflects their English proficiency level. That means most of the students are rather weak in English and it is sensible that they feel urgent to improve all the EAP skills. A doctoral student often has to read lots of books and articles, take exams and write thesis, so they are anxious to make progress in reading and writing to cope with the books and exams. Listening skills help them to understand better in the classroom and to fully understand the lectures given in the international conference. English is not learned for communication, but from communication (Jeremy, 2000). The enhancement of speaking abilities will prepare them better performance in communication and in the future interview.

In summary, EAP course should focus more on doctor candidates' input ability to lay a solid foundation for the future output ability in the academic field.

\section{Situation of Learners' Learning Strategy}

TABLE 3

DATA OF LEARNERS' LEARNING STRATEGY

\begin{tabular}{cccc}
\hline Component & Items & Mean & Standard \\
& & & Deviation \\
\hline Learners' learning strategy & English-native scholars & 4.26 & .82 \\
& Cooperative learning & 4.04 & 1.03 \\
& Ask teachers for help & 4.37 & .83 \\
\hline
\end{tabular}


Table 3 shows the results of learners' expectation of learning strategies. The mean values are all above 4.0 which indicate learners' strong desire to use all the 3 strategies when learning EAP course and their clear consciousness to adopt learning strategy in the process of learning EAP. The mean values show participants tend to ask their teachers for help when they have problems $(\mathrm{M}=4.37, \mathrm{SD}=.83)$. Among three items, the percentage in cooperative learning with members in study group shows the most uncertainty, probably suggesting some of the students prefer to study alone. Participants' likeliness to communicate with English-native scholars may be largely due to the desire to enhance all aspects of capacity in EAP skills. The competence of English learning strategy is nurtured (Cheng Xiaotang \& Zheng Min, 2002). Therefore, teacher's guidance is of necessity in the learning process. In short, more attention should be paid to the training of cooperative learning strategy.

\section{Situation of Learners' Expectation on Classroom Teaching}

TABLE 4

DATA OF CLASSROOM TEACHING

\begin{tabular}{cccc}
\hline Component & Items & Mean & $\begin{array}{c}\text { Standard } \\
\text { Deviation }\end{array}$ \\
& & & 1.08 \\
Classroom & Diversified classroom activities & 4.01 & .97 \\
teaching & Communicate more about thesis & 3.33 & .92 \\
& Multiple teaching modes & 3.99 & .91 \\
\hline
\end{tabular}

As Table 4 presents, the means of the four items are above 3.0, which imply that the participants' EAP learning needs for classroom teaching are at a relatively high level. As to the specific ones, the highest mean value is that of authentic simulated exercise, reaching 4.26 ( $\mathrm{SD}=.91)$, followed by that of diversified classroom activities $(\mathrm{M}=4.01, \mathrm{SD}=1.08)$, and $(\mathrm{M}=3.33, \mathrm{SD}=.97)$ on communicating more about thesis being the last. In classroom teaching, students' expectation towards teacher and classmates is similar to that of learning strategy. More students (84\%) want to communicate more with teachers compared with joining in communicative classroom activities such as group-discussion (72\%). In other words, doctoral candidates trust their teacher more. Additionally, $72 \%$ of the students expect for multiple teaching modes and methods, which echoes the rather high demand in teachers' quality. As for the authentic simulated exercise, a great majority of students $(85 \%)$ consider it as a helper in their international academic exchange, which coincides with their strong motivation to be excellent in academic study.

Therefore, an EAP learning environment accompanied by various classroom activities and authentic academic exchange context are what students need; besides, a ready-guide teacher who can apply diversified teaching modes and methods in welcomed in EAP lesson.

4. Situation of Learners' Expectation on Learning Resource

TABLE 5

DATA OF LEARNING RESOURCE

\begin{tabular}{cccc}
\hline \multicolumn{1}{c}{ DATA OF LEARNING RESOURCE } & Mean & $\begin{array}{c}\text { Standard } \\
\text { Deviation }\end{array}$ \\
\hline Component & Items & 3.84 & 1.11 \\
& & 4.26 & .97 \\
Learning & Regular English activities & .51 & .68 \\
resource & Cooperate with distinguished universities & 4.50 & .84 \\
& Enlarge English electronic resources & 4.15 & 1.05 \\
\hline
\end{tabular}

This table draws a clear picture about doctoral candidates' needs on learning resources. Almost everyone (98\%) hopes that their universities can provide academic activities such as international academy exchange conference according to the data of subsidy column with the mean value being the highest among all the items $(\mathrm{M}=4.68, \mathrm{SD}=.51)$. However, fewer students (67\%) call for necessity to hold regular English activities, since more students want to develop their input ability such as listening and reading skill showed by Table 4-3 and they want to focus more on academic study according to Table 4. More than half of students shows very strong desire to access sorts of learning resource.

All in all, most doctor candidates are thirsty for EAP learning. Hence, corresponding learning resources in the university should keep pace with students' needs.

\section{Situation of Learners' Expectation on Teaching Material}

TABLE 6

DATA OF NEEDS FOR TEACHING MATERIAL

\begin{tabular}{c|c|c|c}
\hline Component & Items & Mean & $\begin{array}{c}\text { Standard } \\
\text { Deviation }\end{array}$ \\
\hline \multirow{3}{*}{ Needs for } & EAP knowledge & .98 \\
Teaching & scientific research & 4.08 & .96 \\
material & practicable extracurricular readings & 4.39 & .96 \\
& research communicative competence & 4.06 & .96 \\
& professional English competence & 4.30 & 1.00 \\
& Job application & 3.00 & 1.15 \\
\hline
\end{tabular}


According to Table 6, of all the contents, the mean of scientific research is the highest, up to 4.39 (SD=.96) conversely, that of job application comes in last with $3.64(\mathrm{SD}=1.15)$; and other contents all get a mean above 4.0. On the whole, the means are all above 3.0, which imply that the participants' EAP learning needs for teaching materials are at a relatively high level. Both Harmer (1983) and Cunningsworth (1995) deem that the best teaching material is the one that satisfy the needs of learners. Seeing from the description, all the items are related to participants' attitude toward the EAP teaching material they are adopting currently, which reflects the EAP teaching material they want. From the data of professional English competence $(\mathrm{M}=4.00, \mathrm{SD}=1.00)$ and job application $(\mathrm{M}=3.64, \mathrm{SD}=1.15)$, students are really less concerned about applying for a job and $81 \%$ of the participants expect teaching materials to be helpful for improving their capacity for scientific research in English, in conformity with their less-strong motivation for a job and stronger motivation for academic study again.

To sum up, the research results above reveal students' very strong desire to use the teaching material to build their academic knowledge and cultivate their academic ability.

\section{Situation of Learners' Expectation on Assessment}

TABLE 7

\begin{tabular}{cccc} 
& \multicolumn{2}{c}{ DATA OF ASSESSMENT } & \\
\hline Component & Items & Mean & Standard \\
& & & Deviation \\
\hline Assessment method & summative assessment & 3.59 & 1.14 \\
& formative assessment & 4.40 & .87 \\
& the combination & 4.18 & .96 \\
\hline
\end{tabular}

In Table 7, each item in the dimension of assessment has a mean above 3.0, ranging from 3.59 ( $\mathrm{SD}=1.14$ ) (summative assessment) 4.40 ( $\mathrm{SD}=.87$ ) (formative assessment). The mean of formative assessment is the highest, followed by the combination of summative assessment and formative assessment $(\mathrm{M}=4.18, \mathrm{SD}=.96)$ and summative assessment. The result is consistent to the frequencies of agreement responses of each item. Most of participants (87\%) in formative assessment, which shows doctoral candidates prefer formative assessment than summative assessment and combination of them. Besides, $84 \%$ of the participants agree on the combination of summative and formative assessment on EAP class. Altogether, majority of participants tend to choose both forms of assessment. The result is consistent with Zhao's (2011) and Meng's (2012) findings: students' scholar performance should be judged by various way such as the combination of oral report, group presentation and course paper.

In brief, the combination of formative and summative assessments can reflect the whole process of EAP learning, which ought to be adopted on course assessment.

\section{IMPLICATIONS FOR EAP COURSE}

Based on the results above, some suggestions are made for the present EAP teaching, EAP Curriculum Design and EAP Teachers based on the findings.

First, doctoral candidates' EAP learning proficiency directly relates to EAP teachers' quality and personal competence. Teachers have to focus on self-cultivation of every aspect of EAP skills to set the best example to the students. Then, it's teachers' duty to help students to form stable learning motivation, like developing intrinsic motivation on academic study. What's more, teachers had better train students to apply efficient learning strategies which can directly enhance the efficiency of learning.

With respect to EAP curriculum design, the pinpoint is to design syllabus for different majors which pose a different requirement for English. It is better for them to learn English connected to their own major. Besides, courses of academic writing are urgently needed. Theories like research method and academic writing patterns integrating with practical English academic writing including writing standards and writing strategies ought to be taught to doctoral students.

With regard to EAP teaching, each aspect of EAP teaching impact students as well as other factors. First of all, diversified activities ought to be arranged to improve learners' academic ability. For example, topic debate on certain academic topic, presenting international articles, personal opinion statement of academic issues in English can be employed. Secondly, it is of great urgency to enrich EAP learning resources. Establishing EAP self-learning platform, cooperating with other universities and extending the electronic resources are good ways. In addition, teaching materials may be practical extracurricular readings, concerning about how to guide students to conduct scientific research and make an academic exchange. Furthermore, the combination of formative assessment and summative assessment will contribute a lot to doctoral candidates.

\section{CONCLUSION}

The study aims to find out the overall situation of doctoral candidates' EAP needs. They harbor a very strong expectation toward EAP course. In addition, of all the nine dimensions, learning resources is what students expect most. Followed by individual wants and learning strategy, reflecting that students' desire to learn EAP and their learning 
self-consciousness is high. Besides, doctoral candidates show relatively high expectations of assessment method, teaching material and classroom teaching.

\section{REFERENCES}

[1] Berwick, R. (1989). Needs assessment in language programming: From theory to practice. R. K. Johnson (ed.). The Second Language Curriculum. Cambridge: Cambridge University Press.

[2] Chen, I-Ju., Chang, Yung-Hao., \& Chang, Wei-Huan. (2016). I learn what I need: Needs analysis of English learning in Taiwan. Universal Journal of Educational Research, 4(1): 1-5. https://doi.org/ 10.13189/ujer.2016.040101.

[3] Chen, Bingbing. (2010). Theoretical construction of college English needs analysis model. Foreign Language Research, (2): 120-123. https://doi.org/10.16263/j.cnki.23-1071/ h.2010.02. 027.

[4] Cheng, Xiao-Tang., \& Zheng, Ming. (2002). Strategies in English Learning. Beijing: Foreign Language Teaching and Research Press.

[5] Chowdhury, T. A., \& Haider, M. H. (2012). A Need-based evaluation of the EAP courses for the pharmacy students in the University of Asia Pacific (UAP), Bangladesh. Asian Social Science, 8 (15): 93-107. https://doi.org/ 10.5539/ass. v8n15p93.

[6] Cunningsworth, A. (1995). Choosing Your Coursebook. London: Macmillan.

[7] Dudley-Evans, J., \& St. John. (1998). Developments in English for Specific Purposes: A Multi-disciplinary Approach. Cambridge: Cambridge University Press.

[8] Harmer, J. (1983). The Practice of English Language Teaching. London: Longman.

[9] Hutchinson, T., \& Waters, A. (1987). English for Specific Purposes. Cambridge: Cambridge University Press.

[10] Iizuka, T. (2019). Task-based needs analysis: Identifying communicative needs for study abroad students in Japan. System, 134-142. https://doi.org/ 10.1016/j.system.2018.11.005.

[11] Jeremy H. (2000). How to Teach English. Beijing: Foreign Language Teaching and Research Press.

[12] Köse, D. G., Yüksel, I., Öztürk, Y., \& Tömen, M. (2019). Turkish academics' foreign language academic literacy: A needs analysis study. International Journal of Instruction, 12(1): 717-736.

[13] Lu, Yi. (2009). Needs analysis of English learning of graduate students in medical major and its teaching implications. China Higher Educational Research, (6): 81-82. https://doi.org/ 10.16298/j.cnki.1004-3667.2009.06.003.

[14] Meng, Lan. (2012). The reform of public English teaching for graduates students under students' needs. Social Science in Guangxi, (6):186-188. https://doi.org/ :10.3969 /j. issn.1004-6917. 2012.06.045.

[15] Menggo, S., Suastra, I. M., Budiarsa, M., \& Padmadedwi, N. N. (2019). Needs analysis of academic-English speaking material in promoting $21 \mathrm{st}$ century skills. International Journal of Instruction, 12(2): 739-754. https://doi.org/ 10.29333/iji.2019.12247a.

[16] Mohammed, S. (2016). Investigating the application of needs analysis on EAP business administration materials. English Language Teaching, 9 (3): 74-79. https://doi.org/ 10.5539/elt. v9n3p74.

[17] Munby, J. (1978). Communicative Syllabus Design. Cambridge: Cambridge University Press.

[18] Munby, L. (1981). Communicative Syllabus Design: A Sociolinguistic Model for Designing the Content of Purpose-specific Language Programs. Cambridge: Cambridge University Press.

[19] Nafissi, Z., Rezaeipanah, F., \& Monsefi, R. (2017). Pre and post test evaluations of students in the needs-analysis Based EAP course at undergraduate level. Advances in Language and Literary Studies, 8(1): 207-214. https://doi.org/ 10.7575/aiac.alls. v.8n.1p.207

[20] Oanh, D. (2007). Meeting students' needs in two EAP programs in Vietnam and New Zealand: A comparative study. RELC Journal, 38: 324-349. https://doi.org/10.1177/0033688207085850.

[21] Richards, J. C. (2001). Curriculum Development in Language Teaching. Cambridge: Cambridge University Press.

[22] Robinson, P. (1991). ESP today: A practitioner's guide. Hemel Hempstead: Prentice Hall International.

[23] Shu, Ding-Fang. (2004). ELT in China: Problems and Suggested Solutions. Shanghai: Shanghai Foreign Language Education Press.

[24] Sultana, S. (2018). Need Analysis: An invaluable step for successful autonomous learning. English Language Teaching, 7(11): 37-42. http://doi.org/10.5539/elt.v11n7p37.

[25] Tajino, A., James, R., \& Kijima, K. (2005). Beyond needs analysis: soft systems methodology for meaningful collaboration in EAP course design. Journal of English for Academic Purpose, 4: 27-42. https://doi.org/ 10.1016/j.jeap.2004.01.001.

[26] Uzun, K. (2018). English for academic purposes needs of research assistants: A qualitative needs analysis in a nursing department. International Journal of Contemporary Educational Research, 5(1): 17-25.

[27] Wen, Qiufang. (2012). Challenges faced by college English and its countermeasures from the perspective of teaching theory. Foreign Language Teaching and Research (bimonthly), (3): 283-292. https://doi.org/ 10.3969/j.issn.1009-6426.2014.09.012.

[28] Widdowson, H. G. (1987). The roles of teacher and learner. ELT Journal, 41(2), 83-88. https://doi.org/10.1093/elt/41.2.83.

[29] Youn, J. S. (2018). Task-based needs analysis of L2 pragmatics in an EAP context. Journal of English for Academic Purposes, (36): 86-98. https://doi.org/ 10.1016/j.jeap.2018.10.005.

[30] Yürekli, A. (2012). An analysis of curriculum renewal in EAP context. International Journal of Instruction, 5(1): 49-68.

[31] Zhao, Bin-Li. (2011). On the structural mismatch of graduate English teaching system. Continuing Educational Research, (4): 89-90. https://doi.org/CNKI:SUN:JIXE.0.2011-04-038.

[32] Zhao, Qing-Hong., Lei, Lei., \& Zhang, Mei. (2009). College English teaching viewed from the perspective of English learning needs of students. Foreign Language World, (4):14-22. 
Xiaoqin Yan was born in Nanchang, Jiangxi Province. She received her PH.D. degree in applied linguistics from Beijing Foreign Studies University.

She is currently an associate professor and master tutor in the Foreign Languages College, Jiangxi Normal University, Nanchang, China. Her research interests include Applied Linguistics and psycholinguistics.

She is an anonymous review expert of Foreign Language Education in China.

Fangfang Zou was born in Jingdezhen, Jiangxi Province. She received her bachelor's degree in Jiangxi Normal University. She is currently pursuing a master's degree in the Foreign Languages College, Jiangxi Normal University, Nanchang, China. 